\title{
Phlogopite in magnesian skarns from seven occurrences in the Banatitic Magmatic and Metallogenetic Belt, Romania
}

\section{CRISTINA SAVA GHINET AND STEFAN MARINCEA}

Geological Institute of Romania

Presenting Author: ghinet.cristina@yahoo.com

Phlogopite, ideally $\left.\left(\mathrm{KMg}_{3}\right)\left(\mathrm{Al} \mathrm{Si}_{3} \mathrm{O}_{10}\right)(\mathrm{OH})_{2}\right)$ is the most common mica in the magnesian skarn deposits. Its occurrence is related to the metamorphic processes, during the prograde stage of evolution of the hydrothermal system. Phlogopite from seven magnesian skarn occurrences in Romania (Ocna de Fier, Tincova, Cacova Ierii, Maşca Băişoara, Băiţa Bihor, Pietroasa and Budureasa) was analyzed in order to ascertain optical, chemical, and X-ray data. The mineral is present in the outer skarn zones developed at the contact of igneous bodies of Upper Cretaceous age with dolomite sequences (dolostones or metasomatic dolomites). It associates with forsterite, spinel, diopside and members of the humite group. The magnesian skarn areas are locally overprinted by a pyrometasomatic mineralization of iron oxides (hematite, magnetite) and borates (ludwigite, kotoite, szaibélyite), and subordinated, in the hydrothermal phase, by a polymetallic mineralization (galena, sphalerite, pyrite, chalcopyrite). The individual crystals are pseudo hexagonal, up to $10 \mathrm{~cm}$ across, usually occurring as stacks of aggregates of fish scale-like individuals. The color is brownish yellow, red brown or green. The mineral generally forms mono or bi-mineral bands (phlogopite + carbonate or phlogopite + serpentine) with a more or less parallel orientation of the forming crystals, as a consequence of its metasomatic nature. The analyzed samples are compositionally variable; the composition in end members always indicates a phlogopite term with various contents of annite $(0.2-0.5 \mathrm{~mol} . \%)$, the $\mathrm{Mg} / \mathrm{Fe}$ ratio being more than $2 / 1$ in all cases. The highest contents of annite were recorded in the phlogopite samples from Maşca Băişoara, Cacova Ierii and Ocna de Fier, whereas Na-phlogopite substitution is minor in all cases (up to 5\%). Fluorine contents are variable, changing from nearly pure $\mathrm{OH}$-bearing phlogopite (Ocna de Fier) to a variety of F-phlogopite $[\mathrm{F} /(\mathrm{F}+\mathrm{OH})=0.49]$ at Băiţa Bihor. The mean unit-cell parameters are: $a=5.327(1), b=$ 9.223(3), $c=20.155(6)$ and $\beta=94.994(2)$. The $\mathrm{F}$ presence leads to a decrease of $c$ parameter, while Fe-Mg substitution increases the $a$ parameter. 